\title{
Diurnal activity budgeting of Large Whistling Teal Dendrocygna bicolor (Vieillot, 1816) (Anseriformes: Anatidae) in Deepor Beel wetlands, Assam, India
}

\author{
Jyotismita Das ${ }^{1}$, Hemen Deka ${ }^{2} \&$ P.K. Saikia ${ }^{3}$ \\ ${ }^{1}$ Research Scholar, ${ }^{3}$ Associate Professor; Animal Ecology and Wildlife Biology Laboratory, Department of Zoology, Gauhati University, \\ Guwahati, Assam 781014, India \\ ${ }^{2}$ Department of Botany, Gauhati University, Guwahati, Assam 781014, India \\ Email: 1 deeporbeel@gmail.com, ${ }^{2}$ dekahemen8@gmail.com, ${ }^{3}$ saikiapk@rediffmail.com (corresponding author)
}

\begin{abstract}
Diurnal activity budgets of the Large Whistling Tea Dendrocygna bicolor were quantified in Deepor Beel wetlands from March 2007 to January 2008. The study revealed that the Large Whistling Teal utilized $36.1 \%$ of time in resting, $37.1 \%$ in locomotion, $21.8 \%$ of diurnal time in feeding and $3.9 \%$ of diurnal time for preening activity. The teal spent $<1 \%$ time in each, of alert and aggressive behaviours
\end{abstract}

Keywords: Activity, Deepor Beel wetland, Dendrocygna bicolor diurnal, feeding, highest, locomotion, resting season.

The activity budgeting studies quantify the time allocation of animals in behavioural activities (Rave \& Baldassarre 1989). The activity budgeting studies of any waterfowl and other migratory birds can provide an insight into the role of the seasonal use of habitats in relation to the annual cycles of birds. Activity

\author{
Date of publication (online): 26 December 2011 \\ Date of publication (print): 26 December 2011 \\ ISSN 0974-7907 (online) | 0974-7893 (print) \\ Editor: Anwaruddin Choudhury

\section{Manuscript details:} \\ Ms \# 02682 \\ Received 26 January 2011 \\ Final received 25 November 2011 \\ Finally accepted 22 December 2011
}

Citation: Das, J., H. Deka \& P.K. Saikia (2011). Diurnal activity budgeting of Large Whistling Teal Dendrocygna bicolor (Vieillot, 1816) (Anseriformes: Anatidae) in Deepor Beel wetlands, Assam, India. Journal of Threatened Taxa 3(12): 2263-2267.

Copyright: (C) Jyotismita Das, Hemen Deka \& P.K. Saikia 2011. Creative Commons Attribution 3.0 Unported License. JoTT allows unrestricted use of this article in any medium for non-profit purposes, reproduction and distribution by providing adequate credit to the authors and the source of publication

Acknowledgements: Authors acknowledge the University Grant Commission, New Delhi for providing fund as a Research fellowship to conduct the $\mathrm{PhD}$ works. The authors also acknowledge the Chief Conservator of forest (Wildlife Division) to provide permission to conduct the work. Again authors are grateful to Mr. Mazedul Islam, JRF for providing necessary help regarding field work.

\section{OPEN ACCESS | FREE DOWNLOAD (C) (i) (口)}

budgets coupled with habitat analysis have been useful in formulating suitable conservation strategies (Paulus 1984). Activity budgets reflect a combination of factors including an individual's physical condition, social structure and environmental conditions (Paulus 1988). The amount of time allocated to various behaviours is therefore critical in understanding the species' ecological needs and the pressures acting upon individuals.

The family Anatidae has 39 species in Assam, of which, seven species are resident and 32 are migratory in nature (Ali \& Ripley 1983). The Large Whistling Teal Dendrocygna bicolor is a Least Concern species (BirdLife International 2009). This is a residential and local migrant duck often found in mixed colonies with the Lesser Whistling Teal Dendrocygna javanica. In recent years, many works regarding the ecology and behaviour of birds in Assam, such as, Barman \& Talukdar (1994), Choudhury (1993), Das \& Saikia (2010), Saikia (1995), Saikia \& Bhattacharjee (1996 a,b), Saikia (1998, 2000), Devi \& Saikia (2010), Saikia \& Saikia (2011), Singh (1995), Singh et al. (1995), Upadhyaya \& Saikia (2009), Upadhyaya \& Saikia (2010 a,b) are worth mentioning. However, no attention has been given to studying the ecology and behaviour of the Large Whistling Teal in this region.

In Deepor Beel wetlands, the population of the Large Whistling Teal is high (Saikia 2005) in relation to other such wetlands of Assam. During the study period, the population of both the Large $(n=1160)$ and the Lesser Whistling Teals $(n=8002)$ were found to be highest as compared to other avian species. Both the species of teals were found to form large groups viz., 50-500 individuals of mixed flocks. But no special attention has been made previously to study activity budgeting of this particular species. The objective of 
the present study was to quantify the activity budgets of the Large Whistling Teal in Deepor Beel wetlands, the lone Ramsar site of Assam.

\section{Study Area}

Deepor Beel is a large natural wetland having great biological and environmental importance (Saikia \& Saikia 2010). This large water body is home to a variety of migratory birds, amphibians, reptiles, insects, micro and macrophytes, terrestrial weeds, lianas and arborescent taxa of ecological and economic importance (Bera et al. 2008). The Deepor Beel Ramsar site has a total area of $40 \mathrm{~km}^{2}$ of which $4.14 \mathrm{~km}^{2}$ has been declared a bird sanctuary. At maximum flooding the beel increases to $4 \mathrm{~m}$ in depth and during the dry season the depth drops to about $1-1.5 \mathrm{~m}$. Deepor Beel (2603'26"-2609'26' $\mathrm{N}$ and $\left.90^{\circ} 36^{\prime} 39^{\prime \prime}-90^{\circ} 41^{\prime} 25^{\prime \prime} \mathrm{E}\right)$ is situated on the southern bank of the Brahmaputra River (Image 1).

\section{Climate}

Deepor Beel has a meso-thermal climate, characterized by high humidity and moderate temperature. The temperature ranges between 10.6$30^{\circ} \mathrm{C}$. Most rainfall occurs during the monsoon period (May-September). The pre-monsoon season (March-May) has a maximum temperature of $27^{\circ} \mathrm{C}$ and a minimum of $24^{\circ} \mathrm{C}$, and relative humidity between 50.5-76.8 \% (Saikia \& Saikia 2010). The monsoon season (May-September) has a maximum temperature of $32^{\circ} \mathrm{C}$ and a minimum of $27.3^{\circ} \mathrm{C}$. The relative humidity is $82.5 \%$. The retreating monsoon (September-October) has maximum and minimum temperatures of $27^{\circ} \mathrm{C}$ and $25^{\circ} \mathrm{C}$ respectively (Saikia $\&$ Saikia 2010). The relative humidity is $82 \%$. The winter season begins in November and continues until January. The average field temperature during this period remains at $20 \pm 2{ }^{\circ} \mathrm{C}$ and the relative humidity measures about $77.5 \%$. January is the coldest month, with the average minimum temperature at $7^{\circ} \mathrm{C}$, but the minimum temperature occasionally reduces to $6^{\circ} \mathrm{C}$.

\section{Methods}

Focal sampling method (Baldassarre et al. 1988) was generally used to study the activity of the Large Whistling Teal in the study area. The study was conducted from March 2008-January 2009 to analyze the different activity patterns of the Large Whistling

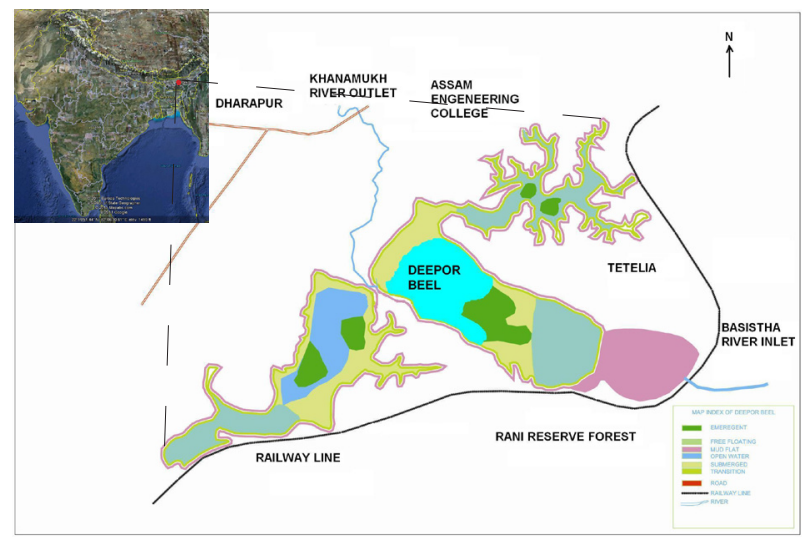

Image 1.Shows the map of the study area

Teal. During the survey period the behavioural data (activity data) were collected at least twice in a month. The total time spent in collecting the data was 260 hours during the 10-month survey period. Diurnal observations were made using a Canon power shot 110 zoom camera and $10 \times 50$ Zenith binoculars. To test the differences in activities in an entire daylight period, each day was divided into different time blocks viz., early morning (0500-0800 hr), morning (0800-1100 hr), midday (1100-1400 hr), afternoon (1400-1600 hr) and dawn (1400-1800 hr) and activity data was collected from these pre-divided time blocks. Large Whistling Teal population data was monitored from a group of mixed colony of Lesser Whistling Teal Dendrocygna javanica. During the study period a flock ( $\mathrm{n}=50$ to 200 individuals) was selected randomly by pointing the binoculars towards the flock and by selecting birds closest to eye distance. Activities of each individual bird were monitored every 15 seconds up to 10 minutes. Activities were categorized as aggression (chasing, biting, threatening), alert (standing or sitting with head or neck protracted), resting (sleeping \& loafing), feeding (searching \& upending), preening (bathing, stretching), locomotion (flying, swimming).

\section{Results}

Resting (36.1\%), locomotion (37.1\%) and feeding $(21.8 \%)$ were the most remarkable activities of the Large Whistling Teal during the study period (Table $1 \&$ Fig. 1). Resting was found to be highest (55.7\%) in January and lowest (18.5\%) in May. In winter it was seen that most of the teal engaged themselves in resting by bending their neck in a peculiar way. 
However, during the day light hours some were seen to rest in a standing position also. Sleeping was mainly observed during the early morning, mid day and late evening hours. Locomotion was reported to be highest (47.8\%) in September and lowest in July $(28.1 \%)$. Locomotion generally could be seen in the form of flying, swimming and walking. Generally in low depth areas the teal prefers to walk, but in open water areas it generally swims to accomplish its purpose. In the case of feeding, the teal absorbed the highest amount of time $(45.4 \%)$ in May and the lowest $(0.52 \%)$ in January. The teal generally used feeding techniques like head dipping, searching and up-ending. Up-ending is the process where the teal first inserts one portion of the head and subsequently the whole body. The Large Whistling Teal spent 3.9\% of diurnal time in preening (Fig. 1). Preening was reported to be highest during October and November $(6.5-6 \%)$ and lowest $(0.6 \%)$ in June. The parts of the body which the teal generally preened were the head and the back of the neck. The Teal spent $<1 \%$ time in each of the alert and aggression behaviours. The Time spent in aggression was the highest $(0.8 \%)$ in March. Aggression was mostly in the form of chasing, biting and threatening. The time spent in alert was the highest (1.3\%) in January 2008. The teal displays alert postures by standing or sitting with the head and neck protracted.

\section{Discussion}

High resting in January might reflect the tendency of the teals to rest in warmer day light hours as January was reported to be the coldest month of the year. Tamisier (1976) had also reported that wintering waterfowl benefit thermodynamically by feeding at night and preening, resting and courting during the warmer day light hours. In fact, the teals were seen to rest over the large floating leaves of Makhana Euryale ferox or other free floating and emergent vegetations. Sometimes, the teals were seen in standing posture over the vegetation patches.

Again, July-August is the main breeding season of of the teal, thus, after breeding, the teals have to move different parts for feeding so, this might be the reason of highest (47.8\%) locomotion activity during September. Likewise, high feeding in May might be due to the fact that, in monsoon season (May-September) the beel becomes fully covered with different emergent, free floating and submerged vegetations. So, the Teals get sufficient feeding material to fulfill their dietary demands. Similar finding was reported by Pyke et al. (1977) in which they mentioned that birds were predicted to allocate the greatest time in habitats with high food abundance and less in areas with low abundance.

High preening during October-November might reflect the fact that individuals completing prealternate moult are the first to form pairs. Rave \& Baldassarre (1989) had also reported high preening in October and November while working on activity budget of the Green-Winged Teal wintering in the coastal wetlands of Louisiana. In waterfowl, as in

Table 1. Diurnal time activity budgets (\%) in Large Whistling Teal in different months

\begin{tabular}{|l|c|c|c|c|c|c|}
\hline Month & Aggression & Alert & Feeding & Resting & Locomotion & Preening \\
\hline March, 2007 & 0.8 & 0.4 & 41.3 & 22.7 & 31.8 & 2.8 \\
\hline April & 0 & 0.7 & 42.5 & 20.3 & 32.5 & 3.7 \\
\hline May & 0.3 & 1.01 & 45.4 & 18.5 & 31.3 & 3.3 \\
\hline June & 0.3 & 0.6 & 30.9 & 23.6 & 43.9 & 0.6 \\
\hline July & 0 & 0.3 & 18.9 & 49.6 & 28.1 & 2.9 \\
\hline August & 0 & 0.2 & 20.5 & 48.2 & 26.2 & 4.5 \\
\hline September & 0 & 0 & 16.5 & 31 & 47.8 & 4.5 \\
\hline October & 0 & 0 & 19 & 32.8 & 41.4 & 6.5 \\
\hline November & 0 & 0.5 & 4.05 & 44.3 & 45 & 6 \\
\hline December & 0 & 1.1 & 0.7 & 50.7 & 41.7 & 5.6 \\
\hline January, 2008 & 0 & 1.3 & 0.5 & 55.7 & 39 & 3.3 \\
\hline Average & 0.1 & 0.5 & 21.8 & 36.1 & 37.1 & 3.9 \\
\hline
\end{tabular}




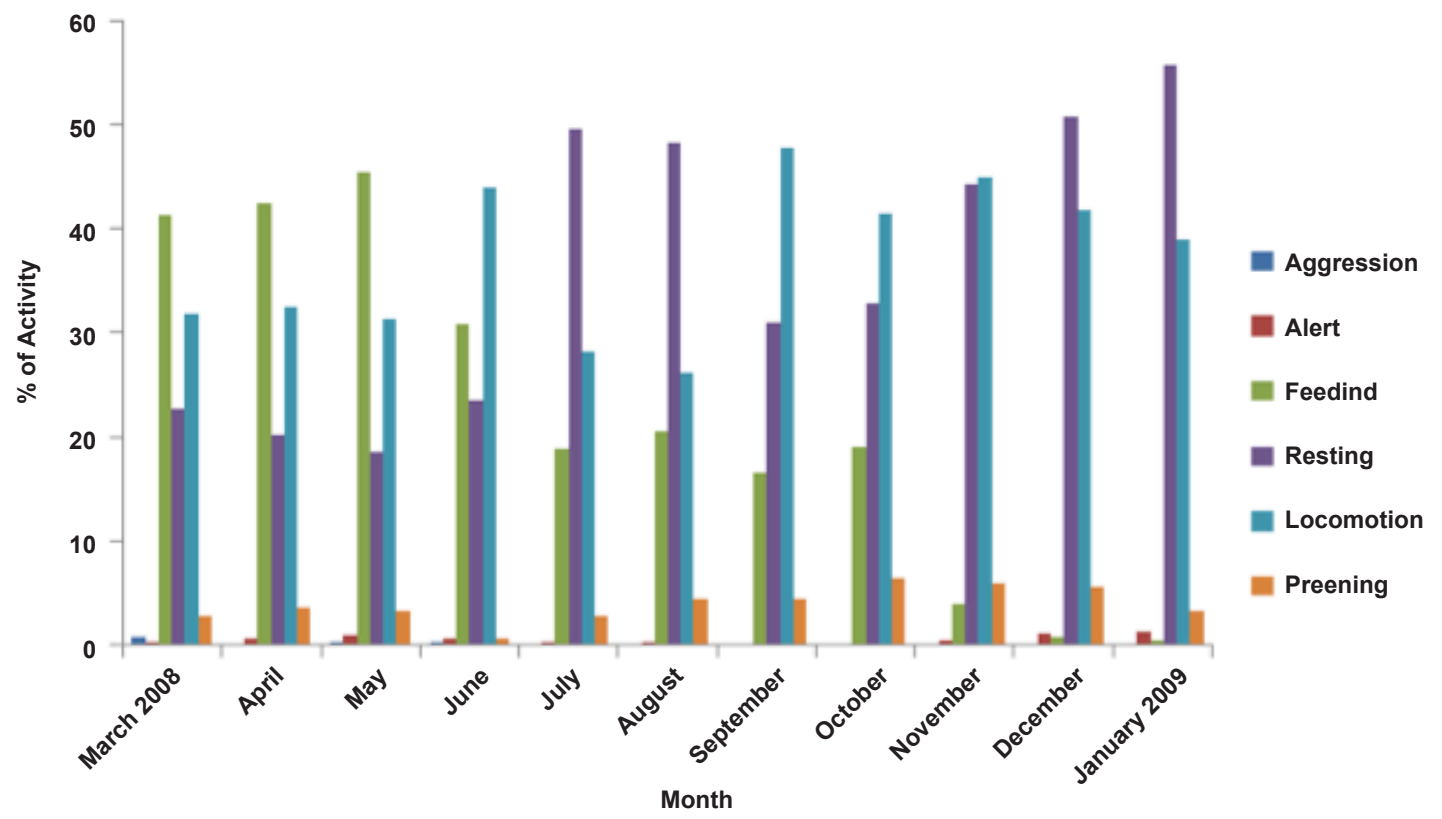

Figure 1. Diurnal activity budget (\%) in Large Whistling Teal

many birds species, females prefer brightly adorned males (Andersson 1994), perhaps because males with the brightest plumages are in the best condition (Hill \& Montgomerie 1994). Female ducks also prefer males that have all of their alternative (breeding) plumage characters fully developed (Klint 1980; Weidmann 1990; Omland 1996).

Highest aggression in March might reflect the frequent encountering of both unpaired and paired teal. Paulas (1983) reported the same findings in case of Gadwalls. Likewise, Rave \& Baldassarre (1989) had reported the high agonistic behaviour in March. High aggression in March might reflect the pair formation and the establishment of breeding territory between teals. Tomkins (1944) reported the same case while working on the Wilson's Plover.

The major factor affecting the high alertness during the winter seems to be due to regular hunting of teal when they form flocks. As winter advances the depth of water of the beel drops to $0.3-0.45 \mathrm{~m}$. As the water level decreases the bird becomes highly alert due to hunting and other life threatening risk factors.

\section{Conclusions}

The study showed that the Large Whistling Teal's activity patterns varied during different months in the Deepor Beel wetlands. The results indicate that the whistling teal exhibits great flexibility in adjusting time budget to maintain its daily requirements. The study documents that the Large Whistling Teal performs different activity patterns to utilize the valuable resources of the beel. The duck prefers mostly aquatic vegetation as a food item. The Beel is also the breeding ground for both the whistling teal species. But the present degradation processes in the form of soil digging, encroachment, agricultural activities, habitat fragmentation in the form of cutting of the beel bed, application of pesticides brings a great danger to the proper survival of this species. Proper management of the beel habitat is quite necessary for the proper survival of the wildlife inhabiting there.

\section{REFERENCES}

Ali, S. \& D. Ripley (1983). Handbook of the Birds of India and Pakistan. Oxford University Press, New Delhi, 737pp.

Andersson, M.B. (1994). Sexual Selection. Princeton, New Jersey, Princeton University Press, Princeton, 599pp.

Baldassarre, G.A., S.L. Paulus, A. Tamisier \& R.D. Titman (1988). Workshop summary: techniques for timing activity of wintering waterfowl, pp. 181-188. In: Weller, M.W. (ed.).Waterfowl in Winter. Minneapolis University. Minnesota Press, USA,

Barman, R. \& B.K. Talukdar (1994). Nesting of Blacknecked Stork Ephippiorhynchus asiaticus in panidihing, Assam. Newsletter for Birdwatchers 36(5): 95.

Bera, S.K, Dixit, Swati \& R. Gogoi (2008). Evidence of bio- 
logical degradation in sediments of Deepor Beel Ramsar site, Assam as inferred by degraded palynomorphs and fungal remains. Current Science 95(2): 178-180.

BirdLife International (2009). Dendrocygna bicolor. In: IUCN 2011. IUCN Red List of Threatened Species. Version 2011.2. <www.iucnredlist.org>. Downloaded on 23 December 2011.

Das, J. \& P.K. Saikia (2010). Studies on the food habit and seasonality of Egrets (Ciconiformes: Ardeidae) in Deepor beel Ramsar site, Kamrup, Assam, pp. 93-100. In: Goswami, U.C., D.K. Sharma, J. Kalita \& P.K. Saikia (eds.). Biodiversity and Human Welfare. Narendra Publishing House, Delhi, 478pp.

Devi, O.S. \& P.K. Saikia (2010). Diversity of frugivorous birds and their habitat use in Jeypore Reserve forest, Dibrugarh District, Assam., pp. 29-36. In: Goswami, U.C., D.K. Sharma, J. Kalita \& P.K. Saikia (eds.). Biodiversity and Human Welfare. Narendra Publishing House, New Delhi, 478pp.

Fredrickson, L.H. \& R.D. Drobney (1979). Habitat utilization by post breeding waterfowl, pp 119-131. In: Bookhout, T.A. (eds.). Waterfowl and Wetlands - An Integrated Review. North-central section, The Wildlife Society Madison, Wisconsin.

Hill, G.E. \& R. Montgomerie (1994). Plumage colour signals nutritional condition in the house finch. Proceedings of the Royal Society of London Series B 258: 47-52.

Klint, T. (1980). Influence of male nuptial plumage on mate selection in the female Mallard (Anas platyrhynchos). Animal Behaviour 28: 1230-1238.

Omland, K.E. (1996). Female mallard mating preferences for multiple male ornaments. II. Experimental variation. Behavioral Ecology and Sociobiology 39: 361-366.

Paulus, S.L. (1983). Dominance relations, resource use and pairing chronology of Gadwalls in winter. Auk 100: $947-$ 952.

Paulus, S.L (1984). Activity budgets of non breeding Gadwalls in Louisiana. Journal of Wildlife Management 48(2): 371-380.

Paulus, S.L. (1988). Time activity budgets of non breeding Anatidae: a review, pp. 135-152. In: Weller, M.W. (ed.). Waterfowl in Winter. Minneapolis: University of Minnesota Press.

Pyke, G.H., H.R. Pulliam \& E.L. Charnov (1977). Optimal foraging: a selective review of theory and tests. The Quarterly Review of Biology 52: 137-154.

Quinland, E.E. \& G.A. Baldassare (1984). Activity budget of non breeding green winged teal on Playa lakes in Pexas. Journal of Wildlife Management 43(3): 838-845.

Rave, P. \& A. Baldassarre (1989). Activity budget of GreenWinged Teal wintering in coastal wetlands of Louisiana. The Journal of Wildlife Management 53(3):753-759.

Reinecke, K.J. (1981). Winter waterfowl research needs and effort in the Mississippi delta. International Waterfowl Symposium 4:231-236.

Saikia, P.K. (1995). Ecobiology of Adjutant Storks with Special reference to Leptoptilos javanicus (Horsfield) in The
Brahmaputra valley Assam. PhD Thesis. Gauhati University, Guwahati, Assam India, 1-357pp.

Saikia, P.K. \& P.C. Bhattacharjee (1996a). Studies on some aspects of the breeding biology of Greater Adjutant Stork, Leptoptilos dubius from the Brahmaputra valley, Assam. Tropical Zoology 1:(1): 57-64.

Saikia, P.K. \& P.C. Bhattacharjee (1996b). Conservation of Greater Adjutant Stork in Assam. A Project Report, Sponsored by WWF, India, 89pp.

Saikia, P.K. (1998). Ecobiology of Adjutant Storks in the Brahpmaputra Valley, Assam. The RF Newsletter 12(1): 18-19.

Saikia, P.K. (2000). Study on the Feeding Behaviour and Dispersion types of Greater Adjutant Storks (Leptoptilos $d u$ bius), Brahmaputra Valley, Assam. India. Journal of Assam Science Society 41(2): 69-80.

Saikia, P.K. (2005). Qualitative and quantitative study of lower and higher organisms and their functional role in the Deepor Beel ecosystem. Project report submitted to North Eastern Space Applications Centre (NESAC), Department of Space, Government of India, Umium, Meghalaya, Shillong, 97pp.

Saikia P.K. \& M.K. Saikia (2010). Biodiversity in Deepor Beel Ramsar Site of Assam India: Faunal Diversity. Lambert Academic Publishing House, Germany, 100pp.

Saikia, P.K. \& M.K. Saikia (2011). Distribution Status and ecology of White-winged Duck and Hornbills in Nameri National Park, Sonitpur, Assam. Zoo's Print 26(11): 1-11.

Singh, H.J., R. Barman, B.K. Talukder, P.K. Saikia \& P.C. Bhattacharjee (1995). Anatomical study of gular pouch in Greater Adjutant Stork. Zoos' Print X(5): 27-28.

Singha, H.J. (1995). Feather collection from a raptor's nest and a note on the Adjutant Stork. Newsletter for Birdwatchers 35: 56.

Tamisier, A. (1976). Diurnal activities of Green-winged Teal and pintail wintering in Louisiana. Wildfowl 27: 19-32.

Tomkins, I.R. (1944). Wilson's Plover in its summer home. Auk 61: 259-269.

Upadhyaya, S. \& P.K. Saikia (2009). Some aspects of breeding behaviour of Indian Cotton Teal (Nettapus coromendelianus coromendelianus Gmelin) in Assam. Journal of Assam Science Society 50(1,2): 164-170.

Upadhyaya, S. \& P.K. Saikia (2010a). Habitat use and activity budgets in Cotton Pygmy-goose in Kadamani wetland, Assam (India). NeBio 1(2): 46-50.

Upadhyaya, S. \& P.K. Saikia (2010b). Activity Budgeting of Cotton Pygmy-Goose in Kadamani Wetland, Assam (India). Proceedings: National Seminar on Biodiversity in North East India 1-9.

Upadhyaya, S. \& P.K. Saikia (2011). Study on display sequences in Cotton Pygmy-Goose Nettapus coromandelianus coromandelianus Gmelin. Journal of Research in Biology 5: 341-345.

Weidmann, U. (1990). Plumage quality and mate choice in Mallards (Anas platyrhynchos). Behaviour 115: 127-141. 